\title{
THE EFFECTIVENESS OF JAPANESE LANGUAGE TRANSLATION METHOD IN THE USE OF DE / NI PARTICIPANTS IN EDUCATORS PRATAMA WIDYA MANDALA BADUNG VOCATIONAL SCHOOL
}

Ni Putu Sri Utami Putri ${ }^{1}$, I Nengah Sudipa ${ }^{2}$ Ketut Widya Purnawati ${ }^{3}$.

Master Study of Linguistic, Faculty of Arts, Udayana University, Bali. e-mail: utamipradana13@gmail.com, nengahsudipa@unud.ac.id,tuti@unud.ac.id

\begin{abstract}
This study aims to determine the effectiveness of the translation method of students of Vocational School Pratama Widya Mandala Badung in Japanese grammar (shokyou bunpo) in the use of particle de / ni. The sample in this study selected by researchers was culinary class XI 1 and culinary XI 2. Culinary Class XI numbered 44 people, with 36 men and 8 women. While students of Class XI Culinary 2 numbered 42 people, with 35 men and 7 women. The method of data analysis is comparational statistics are used which analyze the results of the pretest and posttest with statistical analysis.
\end{abstract}

Keywords: Effectiveness; Vocational School Pratama Widya Mandala Badung; translation method.

\section{INTRODUCTION}

The role of language is very important and needed because language is used to interact with the community. Webster said language is a systematic tool to convey an idea or feeling by using signs, sounds, gestures, or agreed upon signs whose meaning can be understood (in Agnes, 2001: 64). Various kinds of languages exist in this world and each language has its own rules that must be understood by language users, if not mastered the language well, will have difficulty in conveying their intentions to others. Therefore, a good understanding of a language is needed in order to create a smooth communication between 
language users, both with language users from the same country and with language users from different countries. The ability to master a foreign language has become absolute today for people who want progress in themselves, one of which is Japanese. Teaching the basics of Japanese must be done correctly because this is a provision for students to master Japanese well. Learners will experience difficulties because there are many big differences between Indonesian and Japanese. Therefore, a good understanding of a language is needed in order to create a smooth communication between language users, both with language users from the same region, and with language users from different regions. Learning foreign languages, especially Japanese, is a complex matter, especially in the field of grammar. What is learned in the beginner or early stages is the key to successful mastery of foreign languages that will be obtained at the end of learning. In a person's language, it is necessary to know a language that is good and right. Language must be used properly, correctly, and effectively in order to understand what is to be conveyed or the message received in communication or understanding discourse. In other words, if the learner knows and understands grammar well, by itself he can use the language he learns to communicate well too.

Method is a process or systematic way used to achieve certain goals with efficiency, usually in the order of regular, fixed steps. In language teaching, methods are used to express a comprehensive framework of the learning process. The process is arranged in a series of systematic activities, growing from the approach used as a foundation. The nature of a method is procedural. Talking about the problem of using methods in relation to the learning process, the teacher or lecturer must be able to choose and determine the method that is deemed most suitable for use. Since the learning objectives to be achieved are very diverse, the types of methods and approaches used or chosen by lecturers / teachers must also vary according to the characteristics of the learning objectives.

The subjects in this study were students of Primary Vocational School Pratama Widya Mandala Badung. The reason for the selection of students as research subjects is because the ability of students in Japanese language lessons especially basic Japanese grammar (shokyou bunpo) still needs to be improved because this is important as a provision for students to face the School Exams. Before conducting the research, initial observations were made in advance, which aimed to identify the problem of Japanese grammar learning (shokyou bunpo) at Widya Mandala Vocational School in Badung.

Student test results are still below the Minimum Mastery Criteria (KKM) which must reach a value of 70 . The test results also indicate that most students still experience difficulties in learning basic Japanese grammar (shokyou bunpo), both in the use of Japanese predicate, use particles, structure or sentence patterns, as well as in determining the meaning of Japanese sentences. This is due to the method applied by the teacher in Japanese grammar (shokyuo bunpo) which only uses the lecture method. In Japanese grammar learning (shokyou bunpo) must be done with methods that emphasize the rules of Japanese in detail, because Japanese different from Indonesian. Based on the background of 
the problems that have been described previously, the research used was an experimental method with the design of the village pretest and posttest control group. The population of this research is students of class XI with a sample of experimental class students. The problems in this study can be formulated as follows :

1) What is the ability of Japanese grammar (shokyou bunpo) in the use of de / ni particles in students of Widya Mandala Badung Vocational School before applying the translation method?

2) How is the Japanese grammar ability (shokyou bunpo) in the use of de / ni particles in students of Widya Mandala Badung Vocational School after applying the translation method?

3) How is the effectiveness of the method of translation of students of Vocational School Pratama Widya Mandala Badung in Japanese grammar (shokyou bunpo) in the use of de / ni particles?

Literature review gives an explanation of the research that has been done by previous researchers. In this literature study focused on the acquisition of information in the form of theories, concepts, and methods used in research, so as to clarify its usefulness related to this research. Several studies that were reviewed in previous studies were used as input for this research. Minarso's research (2010) in a thesis entitled "Improving Writing Skills Using Grammar Translation Method Through Portfolio Assessment". (An Action Research for students of class VIII MTsN Plupuh 2006/2007 academic year) ". The purpose of this study is to describe the effectiveness of the application of the Grammar Translation Method in improving students' writing skills. The results of this study indicate that: (1) teaching using the Grammar Translation Method through Portfolio Assessment can improve students 'writing skills in: (a) increasing students' knowledge in vocabulary, spelling, punctuation, and grammar, (b ) learners know their mistakes in writing and can correct their own writing correctly, (c) the teacher knows the value of writing each student.

\section{Method}

This research uses a qualitative research approach, qualitative research emphasizes more on language or linguistics as a research tool. This type of research uses experimental research methods. Quasi Experiments are used to determine the effect of the effectiveness of translation methods in Japanese grammar on students' critical thinking skills. This study will compare the pretest and posttest scores of the experimental class. Then the pretest and posttest data from the two classes were analyzed to see whether there were significant differences or effects between the learning models in the experimental class and in the control class.

In the study there was a pretest, before being treated. Thus the results of the treatment can be known more accurately, because it can compare with the conditions before 
being given treatment. In this study aims to find out and investigate the presence or absence of influence and causal relationships of a model or teaching method that is conducted or tested by researchers by providing specific treatment in several groups tested, namely in the experimental group that has been determined. In each class the sample is given a different treatment. The first class as an experimental class is given treatment by applying the translation method. The second class as a control class is given the application of learning that does not apply the method of translation.

Table 1. Research design

\begin{tabular}{|l|l|l|l|}
\hline Group & Pretest & Treatment & Postest \\
\hline Ekperiment & Y1 & $\mathrm{X} 1$ & $\mathrm{Y} 2$ \\
\hline Control & $\mathrm{Y} 1$ & $\mathrm{X} 2$ & $\mathrm{Y} 2$ \\
\hline
\end{tabular}

Data collection methods and techniques applied in this study are by making direct relations to the object under study through observation, interviews, documentation, and literature. The method of data analysis is comparational statistics are used which analyze the results of the pretest and posttest with statistical analysis. In this study comparative statistics are used which analyze the results of the pretest and posttest.

Table 2. Categories of Student Ability Levels

\begin{tabular}{|l|l|l|}
\hline No & \multicolumn{1}{|c|}{ Score (\%) } & \multicolumn{1}{|c|}{ Ability Levels } \\
\hline 1 & $90-100 \%$ & Very Good (A) \\
\hline 2 & $80-89 \%$ & Good (B) \\
\hline 3 & $70-79 \%$ & Good Enough (C) \\
\hline 4 & $35-54 \%$ & Not Good (D) \\
\hline 5 & $0-34 \%$ & Not Very Good (E) \\
\hline
\end{tabular}


The results of data analysis in this study will be presented in formal and informal forms. In this case the formal method is described using statistical presentation in the form of numbers and tables, charts, graphs, and others. Whereas the informal method of presentation uses strings of ordinary words so that they appear detailed and decomposed.

\section{Results and Discussion}

\subsection{Results}

Research results in culinary class XI that include quantitative and qualitative data. The results of quantitative data were obtained from the pretest and posttest results of students. The results of these tests are compared to determine the effectiveness of the ability to master Japanese grammar before and after applying the translation method in the Japanese grammar learning process. The results of qualitative data obtained from the results of test analysis in the form of narrative, questionnaire, interview.

In the initial test the number of students who received a very good predicate was 1 student, who received a good predicate as many as 13 students, who received enough honors as many as 10 students, who received the predicate less than 20 students. The highest score on this initial test is 90 and the lowest score is 63. As for the results of the final test held after learning, the number of students who received a very good predicate were 3 students, who received a good predicate of 20 students, who received a predicate of as many as 21 students, which gets less predicate does not exist. The highest score on this test is 93 and the lowest score is 72 . With statistical calculations obtained the average value of the $(\mathrm{X})$ initial test is $=73.32$. Standard deviation $(\mathrm{Sd})=7.60$ and for the final test the average value $(\mathrm{X})$ is 79.34 , standard deviation $(\mathrm{Sd})=5.87$.

While in the control class on the initial test the number of students who got good predicate was 16 students, who got enough predicate as many as 13 students, got less as many as 13 students, none of the students got very good, less and none. The highest score on this initial test is 86 and the lowest score is 60 from the maximum score of 100. After learning the final test is held, the number of students who received a very good predicate as many as 4 students, who received a good predicate of 18 students, who received a predicate of as much as 19 students, and those who received less than 1 student. The highest value on this test is 93 and the lowest is 66. From the statistical calculations obtained the average value of the initial test $(\mathrm{X})$ is 75.02 , the standard deviation $(\mathrm{Sd})=7.60$. As for the final test, the average value $(\mathrm{X})$ is 79.40 , the standard deviation $(\mathrm{Sd})=6.58$.

Homogeneity test was conducted to prove that the data obtained from the results of the study were in the form of student learning outcomes (initial and final tests) in both groups from the experimental class and the normal distributed control class. Normality test on the data of the results of this study used the Bartlet test at a significant level $(\alpha=0.05)$ 
with the test criteria itung2calculate $<\chi$ Ctable. The results of the homogeneity test calculation can be seen in table 10 below.

Table 3. Homogeneous test

\begin{tabular}{|c|c|c|c|c|c|}
\hline Group & $\mathrm{N}$ & $\begin{array}{c}\text { Varians } \\
(\mathrm{s})\end{array}$ & $\chi$ 2hitung & $\chi 2$ tabel & Keterangan \\
\hline Eksperiment & 44 & $\mathbf{6 , 7 3}$ & $\mathbf{0 , 8 4}$ & $\mathbf{3 , 8 4}$ & Homogeneous \\
\hline Control & 42 & $\mathbf{7 , 2 5}$ & $\mathbf{1 , 6 6}$ & $\mathbf{3 , 8 4}$ & Homogeneous \\
\hline
\end{tabular}

Based on the table above, the homogeneity test calculation results in the experimental group obtained didapatkan 2 count $=0.84$ and $\chi 2$ table $=3.84$ while in the control group obtained $\chi 2$ count $=1.66$ and $\chi 2$ table $=3.84$. This shows that the data from the two groups have homogeneous variance where the value of $\mathrm{h} 2$ arithmetic $<\chi 2$ tables.

After testing the homogeneity of variance so that the results of the data are normally distributed and get homogeneous variances. Next do the statistical test $t$. Below will be presented data from the statistical test $t$ :

Tabel 4. Differences in initial test between the experimental and control groups

\begin{tabular}{|l|l|l|l|l|l|}
\hline Group & N & Mean & Md & Thitung & Ttabel \\
\hline Eksperiment & 44 & 73,39 & & & \\
\cline { 1 - 3 } Control & 42 & 74,33 & & $-0,43$ & 2,019 \\
\hline
\end{tabular}

From the $t$ test carried out, it can be obtained the $t$-count value of -0.57 which turns out that the value is smaller than the t-table value of 5\% which is 2.019 . Thus it means that the initial test did not have a significant difference between the experimental and control groups. After each group was given treatment the researchers conducted a final test on each group. From the final test data obtained, the difference between the initial test and 
the final test in the experimental group and the control group can be seen in Table 12 below:

Table 5. Differences in the final test of the experimental group and the control group

\begin{tabular}{|c|c|c|c|c|c|}
\hline Group & $\mathbf{N}$ & Mean & Md & Thitung & Ttabel \\
\hline Eksperiment & 44 & 79,32 & \multirow{3}{*}{$-3,89$} & \multirow{3}{*}{$-0,22$} & \multirow{3}{*}{2,019} \\
\hline & & & & & \\
\hline Control & 42 & 79,02 & & & \\
\hline
\end{tabular}

From the $\mathrm{t}$ test conducted, it can be obtained the $\mathrm{t}$-count value of -0.22 which turns out that the value is greater than the t-table value of 5\% which is 2.019 . Thus the final test means that there is a significant difference between the experimental group and the control group. From the final test data obtained, the difference between the initial test and the final test in the experimental group and the control group can be seen in the table below:

Table 6. Calculation of the differences between the initial and final tests of the experimental group

\begin{tabular}{|l|l|l|l|l|l|}
\hline Test & $\mathbf{N}$ & Mean & Md & Thitung & Ttabel \\
\cline { 1 - 5 } Initial & $\mathbf{4 4}$ & 73,39 & & & \\
\cline { 1 - 3 } Final & $\mathbf{4 4}$ & 79,32 & & 10,98 & 2,017 \\
\hline
\end{tabular}

From the t test carried out, it can be obtained the t-count value of 10.98 which turned out to be greater than the t-table value of 5\%, namely 2.017. Thus the final test means that there is a significant difference between the experimental group and the control group. From the final test data obtained, the difference between the initial test and the final test in the experimental group and the control group can be seen in the table below:

Table 7. Calculation of the differences between the initial and final tests of the control group 


\begin{tabular}{|c|c|c|c|c|c|}
\hline Test & $\mathbf{N}$ & Mean & Md & Thitung & Ttabel \\
\hline Initial & 42 & 70,95 & \multirow{2}{*}{4,48} & \multirow{2}{*}{8} & \multirow{2}{*}{2,020} \\
\hline Final & 42 & 75,43 & & & \\
\hline
\end{tabular}

From the $\mathrm{t}$ test conducted can be obtained t-count value of 8 which turned out to be greater than the t-table value of 5\% which is 2.020 . Thus it means that there is a significant difference between the initial test and the final test in the control group.

Based on the test results from the initial test and the final test above, it can be taken a decision that the initial ability of students between the experimental class with the control class is the same while the learning outcomes after receiving treatment are different. Thus the research hypothesis that reads "There are differences in student learning outcomes using the grammar translation method and the lecture method in class XI Culinary 2 SMK Widya Mandala Badung Vocational School" can be accepted.

\subsection{Discussion}

From the research data that has been analyzed, the findings obtained are the average initial test score of the experimental class $=73.32$, this shows the initial ability of students about the material being tested is still very low because generally students have not learned it. In doing this preliminary test students basically make this discourse just by guessing it. After being given treatment in the form of learning with the grammar translation method, a final test was held with an average score of 79.34. An increase in the results of this test, because students get treatment from learning that has been given. In the control group given learning by the lecture method, the average initial test score given was 75.02. As in the experimental class, students generally answer this initial test by guessing because the material being tested has not been learned. While the final test results given after students get the learning treatment with the lecture method, obtained an average value of 79.40, which means an increase compared to the initial test results.

When compared to the average initial test scores of the two study groups, it appears that the experimental class learning outcomes are greater than the control class learning outcomes. This can happen because in the experimental class, using the Grammar Translation Method, where students are required to be more active in the learning process. Students are grouped into small groups consisting of 6 groups (4-5 people per group), Then students are given a liplet containing material. In groups working together, this is done so students can exchange ideas with group members so that each individual can understand the material. Because in this method students are required to be active, the teacher just goes 
around, monitoring student work. In the control class students experience learning activities through the lecture method so that students generally only passively listen to receive lessons. Students are more active in the activity of taking notes and occasionally asking questions. With activities that only listen and take notes, it gives rise to boredom for students, which results in a lack of student attention to the lessons being delivered. From the two learning activities discussed above, it can be understood that in learning with the Grammar Translation Method students get a deeper learning experience so that they get better learning outcomes on argumentation discourse material compared to lecture learning methods.

\section{Conclusion}

The conclusion that can be drawn from the results of the analysis and discussion shows that the achievement of student learning outcomes with the Grammar Translation Method is higher than the lecture method. The application of the Grammar Translation Method can improve the learning outcomes of Japanese students in class XI of Pratama Widya Mandala Badung Vocational School, especially in writing skills. This can be seen from the average value of learning outcomes that have increased, namely the average value of the student's initial test in the experimental group 73.32 and the final test is 79.34 . The standard deviation of the initial test was 7.60 and the final test was 5.87 while in the control group the initial test score was 75.02 and the final test was 79.40. The initial test division standard was 7.60 and the final test was 6.58 .

This indicates that student learning outcomes in the experimental group applying the Grammar Translation Method are better than student learning outcomes in the control class applying the lecture method.

\section{Bibliography}

Achmadi, Abu. 2004. Metodelogi Penelitian. Jakarta: Bumi Aksara.

Adnyana, Dewa. 2015. "Metode Kontekstual (Contextual Teaching And Learning) dalam Pembelajaran Tata Bahasa Jepang Dasar (Shokyou Bunpo) Bagi Mahasiswa Semester III Sastra Jepang STIBA Saraswati Denpasar" (Tesis). Denpasar : Pascasarjana Udayana.

Alfianika, Ninit. 2018. "Metode Penelitian Pengajaran Bahasa Indonesia” Yogyakarta : Deepublish.

Andre Payadnya, I Putu Ade. 2018. Panduan Penelitian Eksperimen Beserta Analisis Statistik Dengan SPSS. Yogyakarta. Deepublish.

Angrayni, Lysa. 2018 "Efektivitas Rehabilitasi Pecandu Narkotika Serta Pengaruhnya

Terhadap Tingkat Kejahatan Di Indonesia” Ponorogo : Uwais Inspirasi Indonesia.

Aqel, M. 2013. "The Effect Of Using Grammar-Translation Method On Acquiring English As A Foreign Language”.Jordan : Mu'tah University. 
Buku Pedoman Kegiatan Akademik SMK PratamaWidya Mandala Badung. 2018

Chaer, Abdul. 2007. Kajian Bahasa Struktur Internal, Pemakaian dan Pemelajaran. Jakarta : Rineka Cipta.

Handoyo, Futuh. 2010. "Meningkatkan Kompetensi Subconscious Grammar dengan Menggunakan Latihan-Latihan Semantico-Syntactic Translation bagi Mahasiswa Jurusan Akuntansi, Politeknik Negeri Malang”.Malang : Program Pascasarjana Universitas Negeri Malang.

Iskandar. 2009. Metodologi Penelitian Pendidikan dan Sosial. Jakarta: Gaung Persada Press

Iskandarwassid dan Sunendar, Dadang. 2009. Strategi Pembelajaran Bahasa. Bandung : PT Remaja Rosdakarya

Kentjono, Djoko. 1982. Dasar-dasar Linguistik Umum. Jakarta : Universitas Indonesia.

Mahsun. 2005. Metodelogi Penelitian Bahasa. Jakarta : PT Raja Grafindo Persada.

Margono S. Drs. 2007. Metologi Penelitian Pendidikan Komponen MKDK. Jakarta : PT. Rineka Cipta.

Minarso. 2010. "Improving Writing Skill Using Grammar Translation Method Through Portfolio Assessment. (Sebuah Action Research untuk siswa kelas VIII MTsN Plupuh tahun akademik 2006/2007)". Solo : Universitas Sebelas Maret.

Nugroho, Sigit. 2008. Dasar-dasar Rancangan Percobaan. Bengkulu: UNIB press.

Nugroho, Sigit. 2008. Statistik Nonparametrika. Bengkulu: UNIB press.

Nursalam. 2008. Konsepdan Penerapan Metodologi Penelitian. Jakarta. SalembaMedika.

Parera, J.D. 2004. Teori Semantik. Jakarta : Erlangga.

Poerwadarminto. 1976. Kamus Umum Bahasa Indonesia. Jakarta : Balai Pustaka.

Salim. 2019. Penelitian Pendidikan : Metode, Pendekatan, dan Jenis.Jakarta : Kencana.

Sarwono. 2006. Metodelogi Penelitian Kuantitatif dan Kualitatif. Yogyakarta: Graha Ilmu.

Slameto. 2003. Belajar dan Faktor-faktor yang Mempengaruhinya. Jakarta: Rineka Cipta.Sudjana. 1996. Metoda statistik. Bandung: Tarsito.

Sudaryanto. 1993. Metode dan Aneka Teknik Analisis Bahasa. Yogyakarta : Duta Wacana University Press.

Sudijono, A. 2011. Pengantar Evaluasi Pendidikan. Jakarta: PT RajaGrafindo Persada.

Sudjianto dan Dahidi, Ahmad. 2004. Pengantar Linguistik Bahasa Jepang. Jakarta : Kesaint Blanc.

Sugihartono. 2001. Nihongo No Joshi Partikel Bahasa Jepang. Bandung : Humaniora Utama Press (HUP).

Sugiyono. 2006. Statistik Untuk Penelitian. Bandung : Alfabeta.

Sukardi. 2008. Metode Penelitian Pendidikan Kompetensi dan Praktiknya. Jakarta: Bumi Aksara

Sutedi, Dedi. 2004. Dasar-dasar Linguistik Bahasa Jepang. Bandung : Humaniora Utama Press (HUP).

Verhaar, J.W.M. 2010. Asas-Asas Linguistik Umum. Yogyakarta : Gadjah Mada University 
Press.

Wendra, I Wayan. 2009. Buku Ajar Penulisan Karya Ilmiah. Singaraja : Undiksha.

Widagdho, Djoko. 1997. Bahasa Indonesia Pengantar Kemahiran Berbahasa Di

Perguruan Tinggi. Jakarta : PT Raja Grafindo Persada.

Yendra. 2018. MengenalImuBahasa. Yogyakarta.Deepublish. 